\title{
Vibrational Circular Dichroism Spectroscopy Study of Paroxetine and Femoxetine Precursors
}

\author{
MARIE URBANOVÁ, ${ }^{1}$ VLADIMÍR SETNIČKA, ${ }^{2}$ PETR BOUŘ,${ }^{2,3}$ HANA NAVRÁtILOVÁ, ${ }^{4}$ KAREL VOLKA ${ }^{2}$ \\ ${ }^{1}$ Department of Physics and Measurements, Institute of Chemical Technology, Technická 5, 16628 Praha 6, \\ Czech Republic \\ ${ }^{2}$ Department of Analytical Chemistry, Institute of Chemical Technology, Technická 5, 16628 Praha 6, Czech Republic \\ ${ }^{3}$ Institute of Organic Chemistry and Biochemistry, Academy of Sciences of the Czech Republic, Flemingovo nám. 2 , \\ 16610 Praha 6, Czech Republic \\ ${ }^{4}$ Department of Organic Chemistry, Masaryk University, Kotlářská 2, 61137 Brno, Czech Republic
}

Received 8 September 2001; revised 31 October 2001; accepted 11 November 2001

Published online 25 April 2002 in Wiley InterScience (www.interscience.wiley.com). DOI: 10.1002/bip.10104

\begin{abstract}
The solution structures of (3R,4S)- and (3S,4R)-4-(4-fluorophenyl)-3-hydroxylmethyl-1-methylpiperidine, which are intermediates in the synthesis of the two pharmaceuticals paroxetine and femoxetine, were studied by vibrational circular dichroism (VCD) spectroscopy. In addition, six derivatives with different substituents attached to the C3 atom were prepared and their VCD and absorption spectra discussed with the aid of $a b$ initio simulations. The VCD spectra were found to be sensitive to the geometry changes. In addition, a subtle variation caused by intermolecular aggregation was apparent in the spectra. The VCD technique can be applied for structural analysis of chiral pharmaceuticals in solutions. (C) 2002 Wiley Periodicals, Inc. Biopolymers (Biospectroscopy) 67: 298-301, 2002
\end{abstract}

Keywords: vibrational circular dichroism; conformation; paroxetine; femoxetine

\section{INTRODUCTION}

Chiral drugs marketed as single enantiomers represent examples where vibrational circular dichroism $(\mathrm{VCD})^{1,2}$ spectroscopy can be conveniently applied. $A b$ initio calculations of VCD spectra are no longer restricted to small mole-

\footnotetext{
Correspondence to: M. Urbanová (marie.urbanova@ vscht.cz).

Contract grant sponsor: Ministry of Education, Youth and Sports; contract grant number: CEZ: MSM 223400008.

Contract grant sponsor: Institute of Chemical Technology at Prague; contract grant number: 444010015.

Contract grant sponsor: Grant Agency, Academy of Sciences of the Czech Republic; contract grant number: IAA4055104.

Biopolymers (Biospectroscopy), Vol. 67, 298-301 (2002)

๑) 2002 Wiley Periodicals, Inc.
}

cules, ${ }^{3,4}$ because they can be used for the interpretation of experimental results for medium sized systems, ${ }^{5,6}$ as well as biopolymers. ${ }^{7,8}$ The piperidine derivatives $(3 \mathrm{~S}, 4 \mathrm{R})$ - and $(3 \mathrm{R}, 4 \mathrm{~S})-4-(4-$ fluorophenyl)-3-hydroxylmethyl-1-methylpiperidine are the key intermediates in the synthesis of the antidepressive drugs paroxetine and femoxetine, respectively. Our previous VCD and NMR study ${ }^{5}$ confirmed the absolute configuration of the $(3 \mathrm{R}, 4 \mathrm{~S})$-enantiomer in solution, indicated its prevalent conformation, and implied that the hydroxyl group mediates intermolecular aggregation in concentrated solutions. In this work we test the influence of hydrogen bond formation on the VCD spectra in detail. We also found it interesting for pharmaceutical purposes to monitor the 

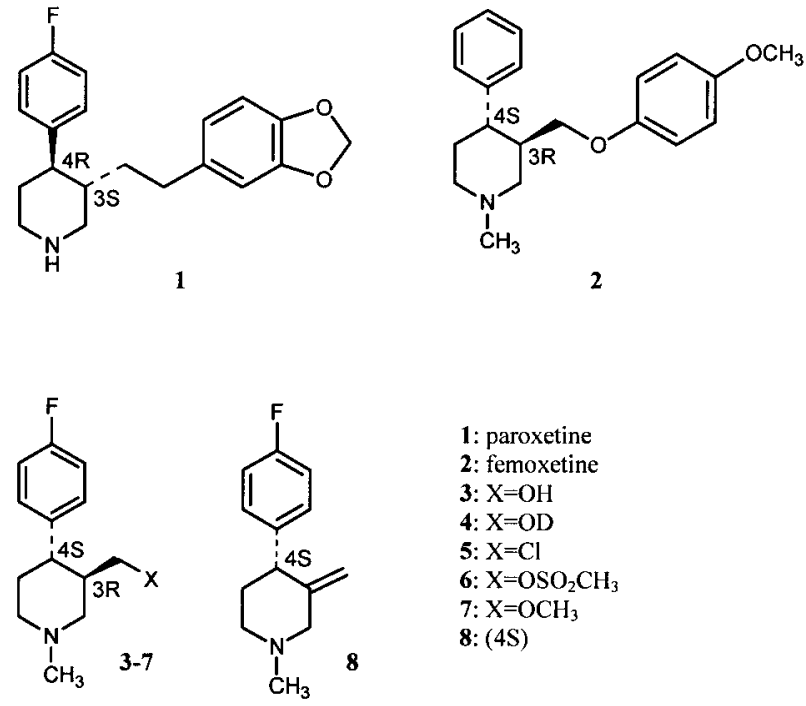

1: paroxetine

2: femoxetine

3: $\mathrm{X}=\mathrm{OH}$

4: $\mathrm{X}=\mathrm{OD}$

5: $\mathrm{X}=\mathrm{Cl}$

6: $\mathrm{X}=\mathrm{OSO}_{2} \mathrm{CH}_{3}$

7: $\mathrm{X}=\mathrm{OCH}_{3}$

8: $(4 \mathrm{~S})$

Figure 1. The structures of the (3S,4R)-4-(4-fluorophenyl)-3-hydroxylmethyl-1-methylpiperidine derivatives.

substitutions of the hydroxyl group by other functional groups and to follow possible conformation changes using VCD.

\section{MATERIALS AND METHODS}

Samples (Fig. 1) of (3S,4R)-3 (100\% ee $)^{9}$ and (3R,4S)-3 (96\% ee) were kind gifts from Synthon BV, The Netherlands. Compounds 4-8 were prepared as described elsewhere. ${ }^{10,11}$ The solutions in $\mathrm{CCl}_{4}$ and $\mathrm{CDCl}_{3}$ within $0.64-0.064 \mathrm{~mol} \mathrm{~L}^{-1}$ were used for the VCD measurements. The VCD and absorption spectra were scanned with a resolution of $4 \mathrm{~cm}^{-1}$ using a Bruker FTIR IFS 66/S spectrometer equipped with the VCD/IRRAS module PMA 37 as previously described in detail. ${ }^{12}$ A demountable cell separated by a 50 - or $200-\mu \mathrm{m}$ Teflon spacer was used.

A simulation of the VCD intensities based on the Gaussian program package ${ }^{13}$ was performed ${ }^{6,7}$ for geometries optimized with the aid of the conformer searching routine implemented in the Spartan program. ${ }^{14}$ The vibrational frequencies and intensities were calculated at the BPW91/6-31+G** density functional theory ${ }^{15}$ level at the harmonic approximation using the MFP/GIAO theory ${ }^{16}$ for VCD. The spectra were simulated using Lorentzian profiles with a $5 \mathrm{~cm}^{-1}$ bandwidth. Normal mode assignment is based on a visual inspection of the dynamic displacements.

\section{RESULTS AND DISCUSSION}

Figure 2 shows the experimental VCD spectra of derivatives 3, 4, and 8 defined in Figure 1. All spectra were recorded with a high $\mathrm{S} / \mathrm{N}$ ratio. Recording of the VCD spectra of $(3 \mathrm{R}, 4 \mathrm{~S})-3$ and $(3 \mathrm{~S}, 4 \mathrm{R})-\mathbf{3}$ reduces the risk of artifacts and confirms the quality of the experimental data: the opposite enantiomers exhibit mirror-image VCD spectra as shown for (3S,4R)-3 and (3R,4S)-3 (Fig. 2 ). For the sake of brevity, we deal only with the $(3 \mathrm{R}, 4 \mathrm{~S})$ enantiomers in the following text.

As an example, the agreement between the experiment and calculation is shown for derivative 7 in Figure 3. The numbers indicate the corresponding vibrational modes. Such a comparison of the absorption and VCD spectra (Fig. 2) for all the derivatives reveals the common features summarized in Table I. The mode numbers of compound $\mathbf{3}$ are used also for the other compounds, because the ordering of the normal modes differs only slightly. Comparing the VCD spectra in Figure 2 , we find that the individual derivatives differ in certain regions where the vibration modes involve the chiral centers $\mathrm{C} 3$ and $\mathrm{C} 4$ and the atoms in their near vicinity (modes 33-39, 47-49, and 58-59).

The VCD measurements require rather high concentrations of the compounds and enable only a narrow interval for concentration variations. In our case we recorded the VCD of $\mathbf{3}$ in $\mathrm{CDCl}_{3}$ and $\mathrm{CCl}_{4}$ solutions with a reasonable $\mathrm{S} / \mathrm{N}$ ratio in the range of $0.64-0.064 \mathrm{~mol} \mathrm{~L}^{-1}$ [Fig. 4(B)]. The observed decrease of the absorption of the free $\mathrm{OH}$

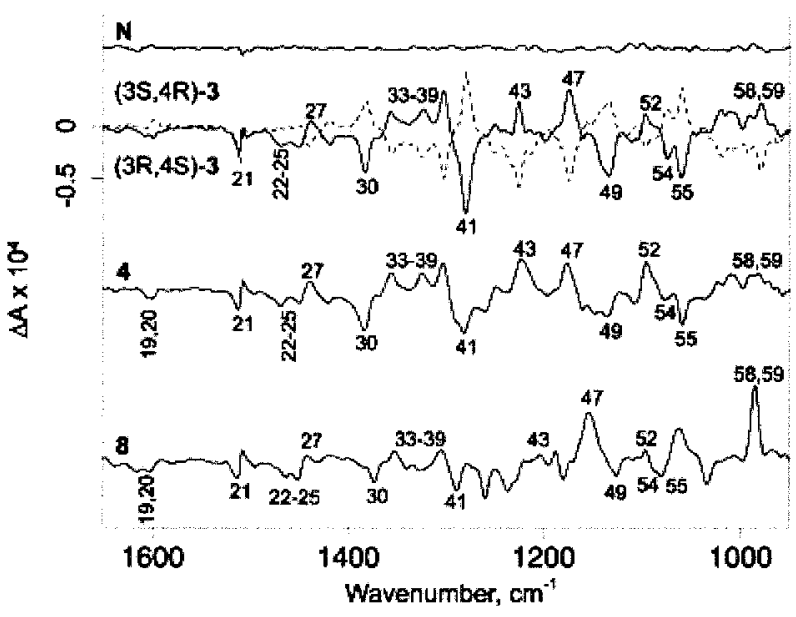

Figure 2. The experimental VCD spectra of derivatives $\mathbf{3}, \mathbf{4}$, and $\mathbf{8}\left(0.64 \mathrm{~mol} \mathrm{~L}^{-1}\right.$ in $\left.\mathrm{CDCl}_{3}\right)$ and the typical noise spectrum $(\mathrm{N})$. 


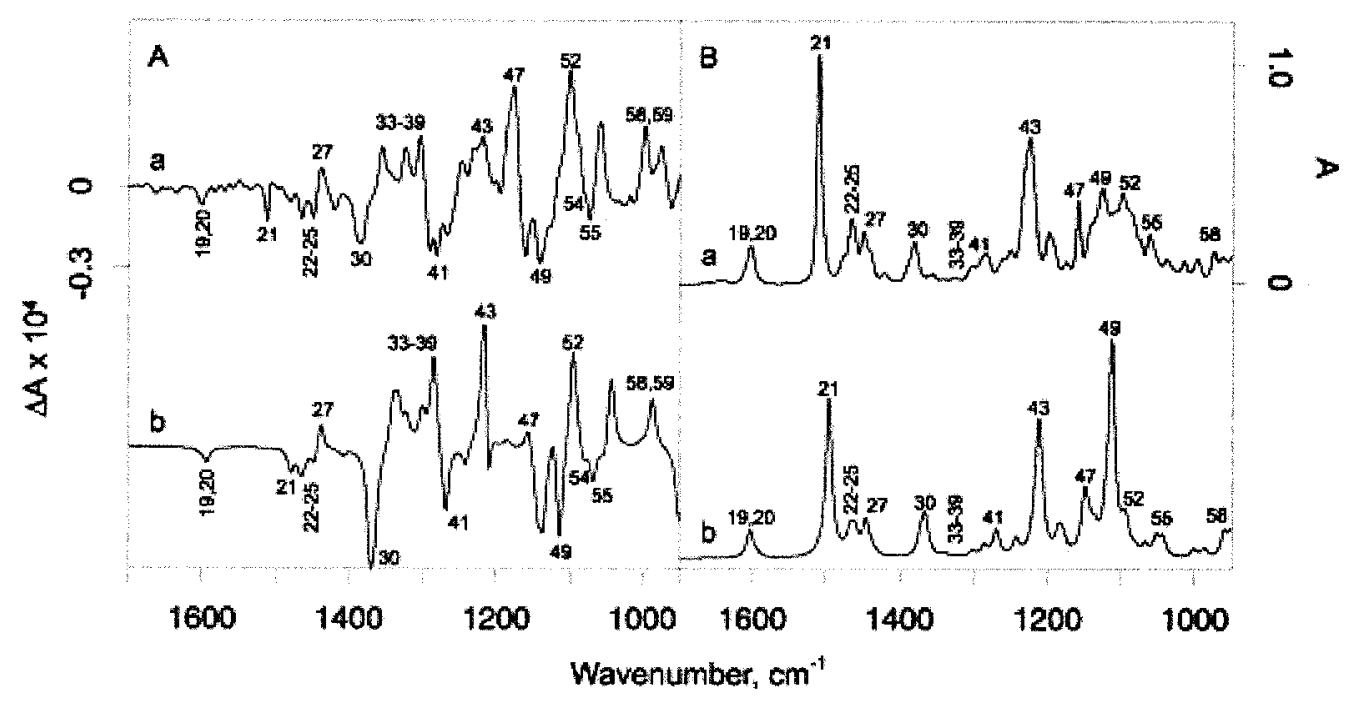

Figure 3. The (A) VCD and (B) absorption spectra of compound 7. The experimental spectra of the $\mathrm{CDCl}_{3}$ solution $\left(c=0.64 \mathrm{~mol} \mathrm{~L}^{-1}\right.$; spectra a) and the simulated spectra (spectra b).

group at $3627 \mathrm{~cm}^{-1}$ and its increase at $3350-3150$ $\mathrm{cm}^{-1}$ for aggregated $\mathrm{OH}$ groups with increasing concentration [Fig. 4(A)] confirmed the hydrogen bond formation. Although the intensity of the free $\nu(\mathrm{OH})$ increases about 2 times as the concentration decreases from 0.64 to $0.064 \mathrm{~mol} \mathrm{~L}^{-1}$, only slight changes were observed in the VCD in the mid-IR region (cf. Fig. 4). This is in accord with our detailed analysis, ${ }^{5}$ which revealed that only limited parts of the spectral region used are affected by the $\mathrm{OH}$ vibrations, for example, the VCD features at $1250-1200$ and $\sim 1000 \mathrm{~cm}^{-1}$ (the gray areas in Fig. 4), which originate in skeletal deformation coupled to or including the $\mathrm{C}-\mathrm{O}$ bond. Also, based on the concentration dependence of the VCD spectra, we can conclude that the aggregation does not have a significant influence on the conformation.

\section{CONCLUSIONS}

The simulated and experimental spectra are in a very good agreement over the entire region of recorded frequencies. The observed variations in the regions specific to the particular substituents could be identified and reasonably explained using the normal mode assignment. In all of the derivatives studied, the substituents do not significantly influence the spectral response of the piperidine skeleton. The theoretical and experimental results suggest that the phenyl and methyl groups are in equatorial positions and the torsion angle $\mathrm{C}$ (substituent)-C3-C4-C(piperidine) is close to $180^{\circ}$ (except 8). The concentration dependence of the VCD and absorption reveals strong intermolecular interactions through hy-

Table I. VCD and Absorption Bands Common to All Derivatives

\begin{tabular}{cccl}
\hline & \multicolumn{2}{c}{ VCD and Absorption Frequencies $\left(\mathrm{cm}^{-1}\right)$} & \\
\cline { 2 - 3 } Mode & Experimental & Calculated & \multicolumn{1}{c}{ Assignment } \\
\hline $19-21$ & 1604,1510 & $1604,1496-1498$ & Phenyl deformation \\
27 & $1439-1440$ & $1437-1447$ & C-H bend (in neighborhood of C3) \\
30 & $1379-1384$ & $1369-1372$ & C-H bend on phenyl \\
41 & $1281-1289$ & $1263-1271$ & $\mathrm{CH}_{2}$ twist and CH Heformation $_{3}$ \\
43 & $1221-1225$ & $1211-1214$ & $\mathrm{C}-\mathrm{F}$ and phenyl deformation \\
52 & 1096 & $1092-1097$ & No specific skeletal vibration \\
55 & $1060-1070$ & $1052-1060$ & Skeletal vibration including C-O \\
\hline
\end{tabular}




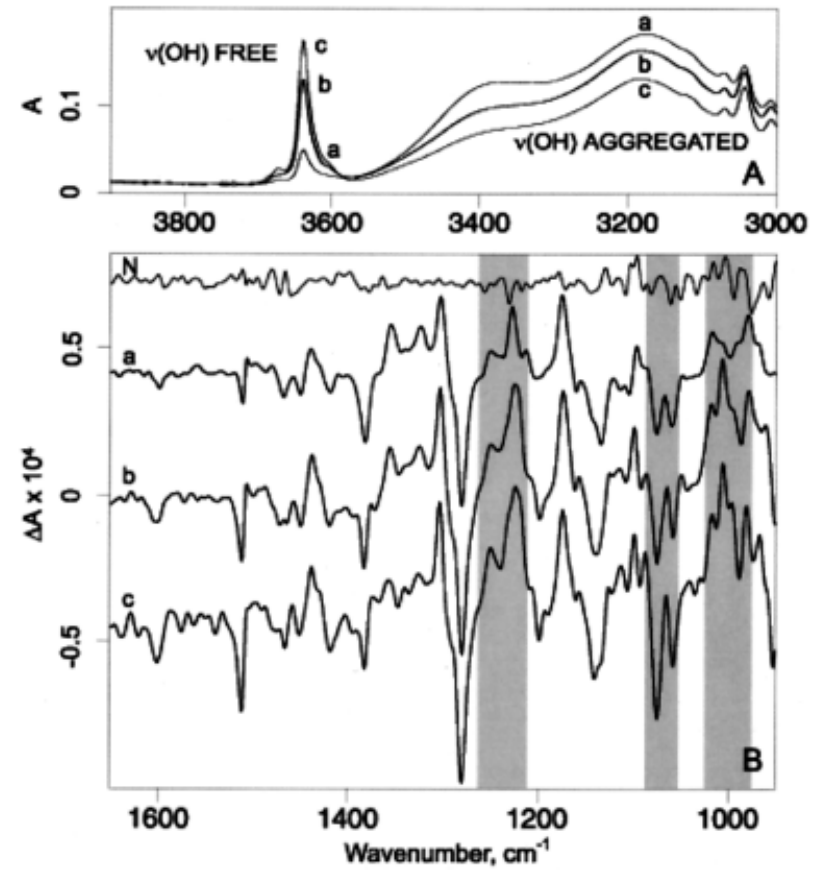

Figure 4. The concentration dependence of (A) the normalized absorption spectra in the $\nu(\mathrm{OH})$ region and (B) the normalized VCD spectra of compound $\mathbf{3}$ in $\mathrm{CDCl}_{3}$ at concentrations of 0.64 (spectrum a), 0.128 (spectrum b), and $0.064 \mathrm{~mol} \mathrm{~L}^{-1}$ (spectrum c) and the noise $(\mathrm{N})$ spectrum for a concentration of $0.128 \mathrm{~mol}$ $\mathrm{L}^{-1}$.

drogen bridges with a minor effect on the molecular conformation.

\section{REFERENCES}

1. Keiderling, T. A. In Practical Fourier Transform Infrared Spectroscopy; Ferraro, J. R., Krishnan, K., Eds.; Academic: San Diego, CA, 1990; pp 203-284.

2. Nafie, L. A.; Freedman, T. B. In Circular Dichroism: Principles and Applications; Berova, N., Nakanishi, K., Eds.; Wiley: New York, 2000; pp 97-132.
3. Bouř, P.; McCann, J.; Wieser, H. J Phys Chem A 1998, 102, 102-110.

4. Tam, C. N.; Bouř, P.; Keiderling, T. A. J Am Chem Soc 1996, 118, 10285-10293.

5. Bouř, P.; Navrátilová, H.; Setnička, V.; Urbanová, M.; Volka, K., J Org Chem 2002, 67, 161-168.

6. Setnička, V.; Urbanová, M.; Bouř, P.; Král, V.; Volka, K. J Phys Chem A 2001, 105.

7. Bouř, P.; Záruba, K.; Urbanová, M.; Setnička, V.; Matéjka, P.; Fiedler, Z.; Volka, K. Chirality 2000, 12, 191-198.

8. Silva, R. A. G. D.; Kubelka, J.; Bouř, P.; Decatur, S. M.; Keiderling, T. A. Proc Natl Acad Sci USA 2000, 97, 8318-8323.

9. Christensen, J. A.; Squires, R. F. U.S. Pat. 4,007,196, 1977.

10. Navrátilová, H. Ph.D. Thesis, Masaryk University, 2001.

11. Navrátilová, H. Chirality 2001, 13.

12. Urbanová, M.; Setnička, V.; Volka, K. Chirality 2000, 12, 199-203.

13. Frisch, M. J.; Trucks, G. W.; Schlegel, H. B.; Scuseria, G. E.; Robb, M. A.; Cheeseman, J. R.; Zakrzewski, V. G.; Montgomery, J. A.; Stratmann, R. E.; Burant, J. C.; Dapprich, S.; Millam, J. M.; Daniels, A. D.; Kudin, K. N.; Strain, M. C.; Farkas, O.; Tomasi, J.; Barone, V.; Cossi, M.; Cammi, R.; Mennucci, B.; Pomelli, C.; Adamo, C.; Clifford, S.; Ochterski, J.; Petersson, G. A.; Ayala, P. Y.; Cui, Q.; Morokuma, K.; Malick, D. K.; Rabuck, A. D.; Raghavachari, K.; Foresman, J. B.; Cioslowski, J.; Ortiz, J. V.; Stefanov, B. B.; Liu, G.; Liashenko, A.; Piskorz, P.; Komaromi, I.; Gomperts, R.; Martin, R. L.; Fox, D. J.; Keith, T.; Al-Laham, M. A.; Peng, C. Y.; Nanayakkara, A.; Gonzalez, C.; Challacombe, M.; Gill, P. M. W.; Johnson, B.; Chen, W.; Wong, M. W.; Andres, J. L.; Gonzalez, C.; HeadGordon, M.; Replogle, E. S.; Pople, J. A. Gaussian 98. Revision A.3 and A.7; Gaussian Inc.: Pittsburgh, PA, 1998.

14. Spartan, P. C. PC Spartan Pro 2000, Pro 1.0.5; Wavefunction Inc.: Irvine, CA, 2000.

15. Becke, A. D. J Chem Phys 1993, 98, 5648-5652.

16. Devlin, F. J.; Stephens, P. J.; Cheeseman, J. R.; Frisch, M. J. J Phys Chem A 1997, 101, 99129924. 